Journal of Economic, Business and Accounting (COSTING)

Volume 1 Nomor 2, Juni 2018

e-ISSN : 2597-5234

https://doi.org/10.31539/costing.vli2.204

\title{
ANALISIS PENGARUH UKURAN PERUSAHAAN, ROA DAN DAR TERHADAP AUDIT DELAY (STUDI EMPIRIS PADA PERUSAHAAN SEKTOR INDUSTRI BARANG KONSUMSI YANG TERDAFTAR DI BURSA EFEK INDONESIA TAHUN 2011-2016)
}

\section{ANALYSIS OF EFFECT OF COMPANY SIZE, ROA AND DAR TO AUDIT DELAY (EMPIRICAL STUDY ON COMPANY SECTORS OF CONSUMPTION INDUSTRY REGISTERED IN INDONESIA STOCK EXCHANGE YEAR 2011-2016)}

\author{
Okalesa \\ Sekolah Tinggi Ilmu Ekonomi Pelita Indonesia \\ okalesa@gmail.com
}

\begin{abstract}
Development of capital market in Indonesia has an impact on increasing demand for financial statement audit. A delay in financial reporting is indirectly interpreted by investors as a bad signal for the company. This study aims to analyze the factors that affect the audit delay in the consumer goods sector companies listed on the Indonesia Stock Exchange (BEI) observation period is 6 years from 2011 to 2016. This test uses multiple linear regression model. The sample of the research is 27 companies engaged in the industry of goods and consumption. The results showed partially firm size, ROA, and DAR have significant effect on audit delay.
\end{abstract}

Keywords: Company Size, ROA, DAR, and Audit Delay

Perkembangan pasar modal di Indonesia berdampak pada peningkatan permintaan akan audit laporan keuangan. Suatu keterlambatan pelaporan keuangan secara tidak langsung diartikan oleh investor sebagai sinyal yang buruk bagi perusahaan. Penelitian ini bertujuan untuk menganalisis faktor-faktor yang mempengaruhi audit delay pada perusahaan sektor barang konsumsi yang terdaftar di Bursa Efek Indonesia (BEI) periode pengamatan adalah 6 tahun dari tahun 2011 sampai dengan 2016. Pengujian ini menggunakan model regresi linier berganda. Sampel dari penelitian berjumlah 27 perusahaan yang bergerak dalam bidang industri barang dan konsumsi. Hasil penelitian menunjukkan secara parsial ukuran perusahaan, ROA, dan DAR berpengaruh signifikan terhadap audit delay.

Kata kunci : Ukuran Perusahaan, ROA, DAR, dan Audit Delay

\section{PENDAHULUAN}

Perkembangan dunia bisnis di Indonesia beberapa tahun terakhir ini sangat pesat. Hal ini ditandai dengan banyaknya perusahaan yang terdaftar di Bursa Efek Indonesia sebagai perusahaan go public. Laporan keuangan merupakan salah satu sumber informasi yang berperan penting dalam pengambilan keputusan dan berfungsi sebagai media komunikasi yang menyampaikan berbagai informasi dan pengukuran secara ekonomis. Menurut Ikatan Akuntansi Indonesia (IAI, 2009), tujuan dari laporan keuangan adalah untuk menyediakan informasi yang menyangkut posisi keuangan, kinerja serta perubahan posisi keuangan suatu perusahaan yang bermanfaat bagi sejumlah pengguna. Oleh karena itu, laporan keuangan akan lebih bermanfaat apabila disajikan secara akurat dan tepat waktu pada saat dibutuhkan oleh para pengguna laporan keuangan, seperti kreditor, investor, pemerintah, masyarakat dan pihak- pihak lain seperti manajemen perusahaan sebagai dasar pengambilan keputusan.

Perkembangan pasar modal di Indonesia berdampak pada peningkatan permintaan akan audit laporan keuangan. Setiap perusahaan yang go public diwajibkan untuk menyampaikan Laporan keuangan tahunan yang dimuat dalam Laporan Tahunan disusun sesuai dengan Standar Akuntansi Keuangan di Indonesia dan telah diaudit oleh Akuntan. Laporan keuangan dimaksud memuat pernyataan mengenai pertanggungjawaban atas laporan keuangan sebagaimana diatur dalam peraturan perundangundangan di sektor Pasar Modal yang mengatur mengenai tanggung jawab Direksi atas laporan keuangan atau peraturan perundang-undangan di sektor Pasar Modal yang mengatur mengenai laporan berkala Perusahaan Efek dalam hal Emiten merupakan Perusahaan Efek. (Salinan Surat Edaran OJK Nomor : 30/SEOJK.04/2016). Hasil audit atas perusahaan publik mempunyai konsekuensi dan 
tanggung jawab yang besar, adanya tanggung jawab yang besar ini memacu seorang auditor untuk bekerja lebih professional, salah satu kriteria profesionalisme dari seorang auditor adalah ketepatan waktu penyampaian laporan auditnya.

Menurut Lestari (2010:19) menyebutkan audit delay sebagai rentang waktu penyelesaian laporan audit laporan keuangan tahunan, diukur berdasarkan lamanya hari yang dibutuhkan untuk memperoleh laporan keuangan auditor independen atas audit laporan keuangan perusahaan sejak tanggal tutup buku perusahaan, yaitu per 31 Desember sampai tanggal yang tertera pada laporan auditor independen.

Sedangkan Menurut (Rachmawati, 2008) nilai dari ketepatan waktu pelaporan keuangan merupakan faktor penting bagi kemanfaatan laporan keuangan tersebut. Selanjutnya menurut Iskandar dan Trisnawati (2010:176), keterlambatan dalam publikasi informasi laporan keuangan akan berdampak pada tingkat ketidakpastian keputusan yang didasarkan pada informasi yang dipublikasikan. Jadi suatu keterlambatan pelaporan keuangan secara tidak langsung diartikan oleh investor sebagai sinyal yang buruk bagi perusahaan. Ketepatan perusahaan dalam mempublikasikan laporan keuangan dapat mengalami keterlambatan yang disebabkan oleh lamanya auditor dalam menyelesaikan pekerjaan auditnya.

Ketepatan waktu penyampaian laporan keuangan pada tahun 2012 dan sebelumnya diatur oleh Bapepam-LK. Bapepam-LK menetapkan bahwa penyampaian laporan keuangan selambat-lambatnya pada akhir bulan ketiga setelah tanggal laporan keuangan tahunan (90 hari) (dalam Surat Keputusan Ketua Bapepam-LK No.36/PM/2003, No. 1 Peraturan X.K.2).

Akan tetapi, pada akhir Desember 2012, pemerintah berkomitmen untuk mengalihkan tugas BAPEPAM-LK ke OJK (Otoritas Jasa Keuangan). Hal ini didasarkan pada Undang-Undang Nomor 21 Tahun 2011 yang berisi "Terhitung mulai tanggal 31 Desember 2012, Tugas dan Fungsi BapepamLK akan berpindah ke Otoritas Jasa Keuangan (OJK)".

Sejak perpindahan itu, penyampaian laporan keuangan yang ditentukan oleh OJK adalah paling lambat pada akhir bulan keempat setelah tahun buku berakhir (dalam Peraturan
Nomor 29/POJK.04/2016 Bab III, Pasal 7, hlm.5).

Faktor-faktor yang dapat mempengaruhi audit delay pada suatu perusahaan yaitu total pendapatan, tipe industri, kompleksitas laporan keuangan, umur perusahaan, laba/rugi perusahaan, ukuran perusahaan, tingkat profitabilitas dan tingkat solvabilitas. Salah satu faktor yang paling mendasar adalah ukuran perusahaan. Maksud dari ukuran perusahaan disini adalah besar kecilnya perusahaan yang diukur dari besarnya total asset atau kekayaan yang dimiliki oleh suatu perusahaan. Faktor ini bisa dijadikan faktor mendasar yang memungkinkan terjadinya audit delay. Menurut pendapat Ristin (2016), Marta Sanjaya dan Wirawati (2016), ukuran perusahaan dapat berpengaruh positif terhadap audit delay. Sementara itu, hasil penelitian Muliadi Candra (2016), Petronila (2007), Kartika (2009) dan Apriliane (2015), ukuran perusahaan berpengaruh negatif terhadap audit delay, yang artinya audit delay akan semakin cepat apabila ukuran perusahaan yang akan di audit semakin besar.

Faktor lain yang berpengaruh terhadap audit delay adalah profitabilitas. Profitabilitas adalah kemampuan perusahaan dalam memanfaatkan asset untuk menghasilkan laba. Untuk melangsungkan hidup perusahaan, suatu perusahaan haruslah berada dalam keadaan menguntungkan/profitable menurut Syamsuddin (2009:59). Hasil penelitian Muliadi Candra (2015) \& Kartika (2009) menunjukan bahwa profitabilitas tidak berpengaruh signifikan terhadap audit delay. Hasil penelitian ini menemukan bahwa perusahaan yang mengalami tingkat keuntungan baik kecil maupun besar cenderung untuk mempercepat proses auditnya. Namun, hasil penelitian Lianto dan Kusuma (2010) menemukan bahwa profitabilitas berpengaruh terhadap audit delay. Hal ini terjadi karena perusahaan dengan tingkat profitabilitas tinggi cenderung memerlukan waktu pengerjaan audit laporan lebih cepat karena ada tuntutan untuk menyampaikan kabar baik secepatnya kepada publik.

Selain faktor profitabilitas, diduga faktor solvabilitas juga berpengaruh terhadap audit delay. Solvabilitas, lebih khususnya rasio hutang modal atau debt to equity ratio, juga diperkirakan menjadi faktor yang berpengaruh terhadap audit delay. Rasio hutang modal, atau disebut juga sebagai rasio leverage, menggambarkan sejauh mana modal pemilik 
dapat menutupi hutang-hutang kepada pihak luar dan merupakan rasio yang mengukur hingga sejauh mana perusahaan dibiayai dari hutang. Menurut Ristin,Fika (2016) dan Candra,Muliadi (2015), semakin banyak jumlah hutang yang dimiliki suatu perusahaan maka akan semakin besar pula tekanan yang dirasakan perusahaan tersebut untuk menyediakan laporan keuangan lebih cepat untuk para kreditor. Hasil penelitian Ani Yulianti (2011), menunjukkan bahwa tidak ada pengaruh yang signifikan dari tingkat solvabilitas terhadap audit delay.

Berdasarkan paparan beberapa penelitian terdahulu yang sudah dilakukan di atas, maka penelitian ini bermaksud mengkaji lebih jauh mengenai faktor-faktor yang mempengaruhi audit delay. Meskipun telah banyak dilakukan penelitian tentang audit delay pada perusahaan yang terdaftar di BEI, namun masih banyak perbedaan hasil. Hasil penelitian tersebut bisa beragam dikarenakan perbedaan dalam pengambilan variabel independen, perbedaan sampel yang diteliti, perbedaan periode pengamatan atau perbedaan dalam metodologi statistik yang digunakan.

Penelitian ini merupakan replikasi dari penelitian sebelumnya yang berhubungan dengan faktor-faktor yang mempengaruhi audit delay. Penulis mengacu pada penelitian yang dilakukan oleh Apriliane (2015) yang mengambil judul faktor-faktor yang mempengaruhi audit delay, objek penelitian yang diambil adalah perusahaan Pertambangan di Bursa Efek Indonesia selama tahun 2008 sampai dengan 2013, faktor-faktor audit delay yang diteliti adalah pos-pos luar biasa, laba atau rugi perusahaan, kompleksitas operasi perusahaan, ukuran perusahaan, opini auditor, reputasi auditor dan konvergensi IFRS.

Adapun perbedaan penelitian ini dengan penelitian sebelumnya yaitu objek sampel yang diambil adalah perusahaan barang konsumsi yang terdaftar di Bursa Efek Indonesia selama tahun 2011 sampai dengan 2016. Selain itu, variabel yang digunakan pada penelitian ini mengkombinasikan beberapa variabel yang digunakan oleh peneliti sebelumnya yaitu ukuran perusahaan,ROA (Return On Asset) dan DAR (Debt to Asset Rasio).

Berdasarkan uraian diatas maka dilakukan penelitian dengan judul "Analisis Pengaruh Ukuran Perusahaan, ROA dan DAR Terhadap Audit Delay (Studi Empiris pada Perusahaan Sektor Industri Barang Konsumsi yang terdaftar di Bursa Efek Indonesia Tahun 2011-2016)".

Tujuan penelitian: Untuk menganalisis pengaruh ukuran perusahaan, tingkat profitabilitas (ROA), tingkat solvabilitas (DAR) terhadap audit delay pada perusahaan sektor industri barang konsumsi yang terdaftar di BEI tahun 2011-2016.

Menurut Arens, Elder, dan Beasley (2010), auditing adalah proses pengumpulan dan evaluasi bahan bukti tentang informasi yang dapat diukur mengenai suatu entitas ekonomi untuk menentukan dan melaporkan kesesuaian informasi dengan kriteria yang telah ditetapkan. Standar auditing merupakan pedoman umum untuk membantu auditor dalam memenuhi tanggung jawab dan profesionalisme mereka dalam mengaudit laporan keuangan. Standar auditing juga mencakup pertimbangan dalam kualitas profesional seperti kompetensi dan independensi, persyaratan pelaporan, dan bukti (Arens, et al, 2010).

Ketepatan waktu penerbitan laporan keuangan auditan merupakan hal yang sangat penting khususnya untuk perusahaanperusahaan public yang menggunakan pasar modal sebagai salah satu pendanaan. Namun auditor memerlukan waktu yang cukup untuk dapat mengumpulkan bukti-bukti kompeten yang dapat mendukung opininya (Destiana, 2011).

Semakin panjang waktu yang dibutuhkan di dalam mempublikasikan laporan keuangan tahunan sejak akhir tahun buku suatu perusahaan milik klien, maka semakin besar pula kemungkinan informasi tersebut bocor kepada investor tertentu atau bahkan bisa menyebabkan insider trading dan rumor-rumor lain di bursa saham (Kartika, 2011). Menurut Yanuarizqi (2013) Audit Delay akan semakin panjang untuk perusahaanperusahaan yang memiliki aset yang besar, kondisi keuangan yang buruk atau kesibukan yang padat menjelang akhir tahun buku.

Perusahaan go publik di Indonesia, dalam hal penyampaian laporan keuangan telah di atur oleh Otoritas Jasa Keuangan dalam Peraturan Nomor 29/POJK.04/2016 tentang Laporan Tahunan Emitmen atau Perusahaan publik menyatakan bahwa Emiten atau Perusahaan Publik wajib menyampaikan Laporan Tahunan kepada Otoritas Jasa Keuangan paling lambat pada akhir bulan keempat setelah tahun buku berakhir (Bab III, Pasal 7, hlm.5). 
Berdasarkan pernyataan-pernyataan di atas, dapat disimpulkan bahwa pengertian audit delay adalah lamanya waktu penyelesaian audit yang diukur dari perbedaan waktu antara tanggal tutup tahun buku perusahaan yaitu per 31 Desember sampai tanggal yang tercantum pada laporan audit independen. Dalam penelitian ini, audit delay diukur dengan membandingkan kedua tanggal itu.

Audit Delay $=$ Tanggal Laporan Keuangan

Menurut Indah Putri (2014) Ukuran perusahaan adalah besar kecilnya perusahaan dapat diukur berdasarkan total nilai aset yang dimiliki perusahaan. Pengukuran ini dihitung dengan natural log berdasarkan total aset yang dimiliki setiap perusahaan sampel. Perusahaan besar lebih konsisten untuk tepat waktu dibandingkan perusahaan kecil dalam menginformasikan laporan keuangannya. (Andi Kartika: 2011). Menurut Rochimawati (2008) ukuran perusahaan adalah suatu ukuran perusahaan yang menunjukkan besar kecilnya perusahaan. Ukuran perusahaan ditandai dengan beberapa ukuran antara lain total penjualan, total asset, log size, jumlah pegawai, nilai pasar perusahaan, dan nilai buku perusahaan. Penelitian ini menggunakan log total aset yang dimiliki perusahaan sebagai ukuran perusahaan.

Ukuran Perusahaan $=\log ($ Total Aktiva $)$

Profitabilitas adalah kemampuan perusahaan dalam menghasilkan laba atau keuntungan selama periode tertentu pada tingkat penjualan, aset, dan modal saham tertentu. Dalam rasio profitabilitas ini dapat dikatakan sampai sejauh mana keefektifan dari keseluruhan manajemen dalam menciptakan keuntungan bagi perusahaan. Perusahaan yang memiliki profitabilitas tinggi cenderung akan melaporkan laporan keuangannya lebih cepat sehingga audit delay-nya akan lebih pendek. Dalam penelitian ini, indikator yang digunakan untuk mengukur tingkat profitabilitas adalah Return On Assets (ROA), rasio ini mengukur kemampuan perusahaan menghasilkan laba berdasarkan tingkat aset tertentu (Kinanti, Irsalina:2012).

\begin{tabular}{|c|c|c|c|}
\hline Profitabilitas $=$ & $\frac{\text { Laba Bersih }}{\text { Total Aktiva }}$ & $\mathrm{x}$ & $100 \%$ \\
\hline
\end{tabular}

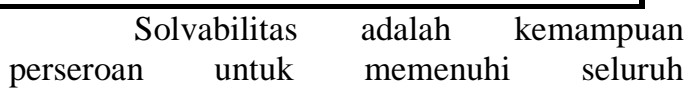

kewajibannya, yang diukur dengan membuat perbandingan seluruh kewajiban terhadap seluruh aktiva dan perbandingan seluruh kewajiban terhadap ekuitas (Kasmir, 2008). Solvabilitas seringkali disebut leverage ratio. Weston dan Copeland (1995) dalam Andi Kartika (2011) menyatakan bahwa rasio leverage mengukur tingkat aktiva perusahaan yang telah dibiayai oleh penggunaan hutang. Dengan demikian solvabilitas merupakan kemampuan suatu perusahaan untuk membayar semua hutang-hutangnya baik jangka pendek maupun jangka panjang. Tingginya rasio debt to equity mencerminkan tingginya resiko keuangan perusahaan.

Solvabilitas perusahaan dalam penelitian ini diukur dengan membandingkan jumlah utang (baik jangka pendek ataupun jangka panjang) dengan jumlah aktiva (Rachmawati, 2008). Angka perbandingan tersebut dinyatakan dalam Debt to Assets Rasio (DAR). Tujuan digunakan Debt to Assets Rasio dikarenakan rasio ini mengindikasikan kesehatan perusahaan.

Solvabilitas $=\frac{\text { Total Hutang }}{\text { Total Aktiva }} \quad \mathrm{x} \quad 100 \%$

Berdasarkan kerangka pemikiran yang telah diuraikan, dapat digambarkan dengan bagan sebagai berikut.

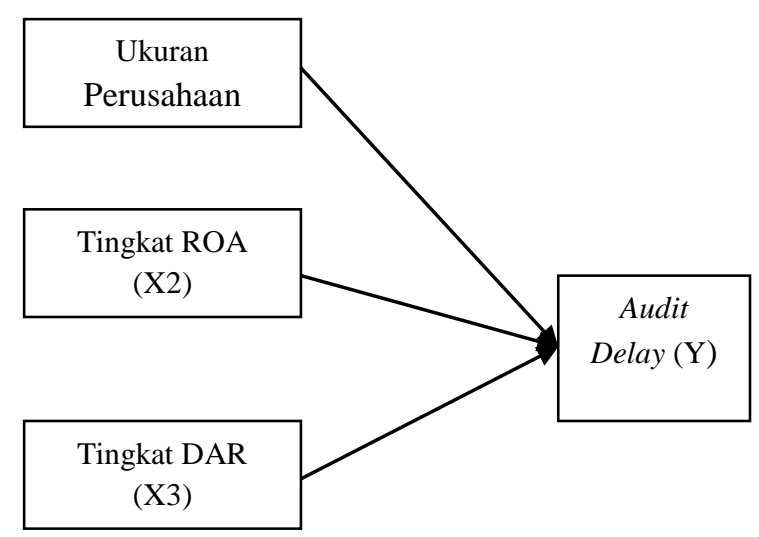

Sumber : Data Olahan

Gambar 1. Skema Kerangka Pemikiran

Berdasarkan kerangka pemikiran di atas dapat dirumuskan hipotesis sebagai berikut: (1) Ukuran perusahaan tidak berpengaruh terhadap audit delay, (2) Tingkat profitabilitas berpengaruh positif terhadap audit delay, (3) Tingkat solvabilitas berpengaruh positif terhadap audit delay. 


\section{METODE PENELITIAN Populasi}

Populasi dapat didefinisikan sebagai keseluruhan kelompok orang, kegiatan, atau sesuatu yang menjadi ketertarikan peneliti untuk diinvestigasi sedangkan sampel adalah sesuatu yang terdapat dalam populasi (Sekaran dan Bougie, 2009:262). Populasi dalam penelitian ini adalah perusahaan sektor industri barang konsumsi yang terdaftar di Bursa Efek Indonesia (BEI) periode 2011-2016. Pengambilan waktu tersebut guna melihat konsistensi hasil penelitian dari tahun ke tahun. Ada sekitar 40 perusahaan industri barang konsumsi yang listing di BEI.

\section{Ukuran Sampel yang Diambil}

Dari 40 populasi yang ada, selanjutnya diambil sampel menggunakan metode purposive sampling, yaitu penarikan sampel dengan pertimbangan tertentu disesuaikan pada kepentingan dan tujuan penelitian.. Alasan menggunakan metode purposive sampling dengan pertimbangan agar sampel yang diteliti memenuhi kriteria untuk diuji dan menghindari bias yang disebabkan oleh adanya perbedaan yang ekstrim. Jadi, jumlah sampel yang akan diteliti adalah sebanyak 27 perusahaan.

\section{Definisi Variabel Penelitian:}

Variabel Independen : Audit Delay, dengan

Indikator: Selisih tanggal penutupan tahun

buku sampai tanggal laporan keuangan audit.

Variabel Dependen : Ukuran Perusahaan, dengan Indikator: $\log$ (Total Aktiva).

Profitabilitas, dengan Indikator : Return on Assets $($ ROA $)=$ Nilai laba bersih dibagi total aktiva dikalikan $100 \%$.

Solvabilitas, dengan Indikator : Debt to Total Assets $(\mathrm{DAR})=$ Total Hutang dibagi total aktiva.

\section{Teknik Analisis Data}

\section{Regresi Linear Berganda}

Menurut Sanusi (2011:134) regresi

linear berganda menyatakan hubungan kausalitas antara variabel independen terhadap variabel dependen. Metode analisis data akan dilakukan dengan bantuan aplikasi komputer program SPSS (Statistical Package For Social Science) versi 20. Adapun model regresi linier berganda yang digunakan sebagai berikut:

$$
\mathrm{Y}=\alpha+\beta_{1} \mathrm{X}_{1}+\beta_{2} \mathrm{X}_{2}+\beta_{3} \mathrm{X}_{3}
$$

Notasi :

$$
\begin{array}{ll}
\mathrm{Y} & =\text { Audit delay } \\
\alpha & =\text { Konstanta } \\
\mathrm{X}_{1} & =\text { Ukuran Perusahaan } \\
\mathrm{X}_{2} & =\text { ROA } \\
\mathrm{X}_{3} & =\text { DAR } \\
\beta_{1} \beta_{2} \beta_{3} & =\text { Koefisien regresi masing- }
\end{array}
$$
masing variabel independen

\section{Analisis Deskriptif}

Analisis deskriptif adalah analisis yang bertujuan untuk membuat deskripsi, gambaran atau lukisan secara sistematis, factual dan akurat mengenai fakta-fakta, sifat-sifat serta hubungan antar fenomena yang diselidiki.

\section{Uji Asumsi Dasar dan Klasik}

Salah satu syarat untuk bisa menggunakan persamaan regresi linier berganda adalah terpenuhinya uji asumsi klasik. Tujuan pengujian asumsi klasik adalah untuk mengetahui apakah hasil estimasi regresi yang dilakukan terbebas dari bias yang mengakibatkan hasil regresi yang diperoleh tidak valid dan akhirnya hasil regresi tersebut tidak dapat dipergunakan sebagai dasar untuk menguji hipotesis dan penarikan kesimpulan. Uji asumsi klasik terdiri dari uji normalitas, uji multikolinearitas, uji autokorelasi dan uji heteroskedastisitas.

\section{Uji Hipotesis \\ Uji Hipotesis Analisis Parsial (Uji t)}

Uji $\mathrm{t}$ digunakan untuk mengetahui apakah secara parsial variabel independen berpengaruh secara signifikan terhadap variabel dependen (Priyatno, 2012:90). Uji hipotesis dalam penelitian ini dilakukan dengan tingkat signifikansi sebesar 5\% dengan derajat kebebasan $\mathrm{df}=(\mathrm{n}-\mathrm{k}-1)$, dimana $\mathrm{n}=$ jumlah observasi dan $\mathrm{k}=\mathrm{jumlah}$ variabel. Dasar pengambilan keputusan dapat dilihat dari nilai $\mathrm{t}_{\text {hitung }}$ yang akan dibandingkan dengan $\mathrm{t}_{\text {tabel }}$. Jika $t_{\text {hitung }}>t_{\text {tabel, }}$ atau signifikansi (probabilitas) $<0,05$ maka $\mathrm{H}_{1}$ diterima dan $\mathrm{H}_{0}$ ditolak. Begitu pula sebaliknya.

\section{Uji Hipotesis Analisis Simultan (Uji F)}

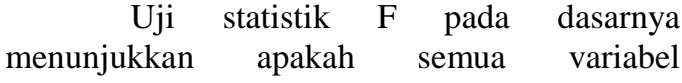
independen yang dimaksud dalam penelitian mempunyai pengaruh secara simultan (bersamasama) terhadap variabel dependen. Uji hipotesis dalam penelitian ini dilakukan dengan tingkat signifikansi sebesar 5\% dengan derajat kebebasan $\mathrm{df}=(\mathrm{n}-\mathrm{k})$ dan $(\mathrm{k}-1)$, dimana $\mathrm{n}=$ jumlah observasi dan $\mathrm{k}=\mathrm{jumlah}$ variabel. Dasar pengambilan keputusan untuk uji $\mathrm{F}$ sama dengan uji t.

\section{Koefisien Determinasi $\left(\mathbf{R}^{2}\right)$}


Uji koefisien determinasi beertujuan untuk mengetahui seberapa besar kemampuan variabel independen menjelaskan variabel dependen (Nugroho, 2005). Nilai hasil dari uji koefisien determinasi ini dilihat dari besarnya nilai adjusted $\mathrm{R}^{2}$, maka akan semakin baik model regresi yang digunakan dalam sebuah model penelitian (Ghozali, 2006). Besarnya koefisien determinasi ini bergerak diantara 0 dan 1. Semakin mendekati 0, maka semakin kecil kemampuan semua variabel independen menjelaskan variabel dependennya. Sebaliknya, semakin mendekati 1, maka semakin besar kemampuan semua variabel independen menjelaskan variabel dependennya. Menurut Sanusi (2011:136) persamaan regresi selalu disertai $\mathrm{R}^{2}$ sebagai ukuran kecocokan.

\section{HASIL DAN PEMBAHASAN}

\section{Hasil Uji Regresi Linear Berganda}

Bentuk persamaan regresi linier dalam penelitian ini sebagai berikut :

$Y=56,653-, 522 X_{1}+0,606 X_{2}+39,493 X_{3}$

Dengan persamaan regresi linier di at $\mathrm{Y}$ dapat dijelaskan bahwa :

Konstanta $\quad(\alpha) \quad$ sebesar $\quad 56,6 . \mathrm{X3}$ memperlihatkan arah hubungan variat Valid $N$ independen yang positif terhadap audit delc(listwise) Artinya apabila $\mathrm{X}_{1}, \mathrm{X}_{2}$, dan $\mathrm{X}_{3}$ bernilai nol (0), maka audit delay bernilai 56,653.

Koefisien regresi variabel $X_{1} \quad\left(\beta_{1}\right)$ bernilai ,522. Hal ini menunjukkan bahwa ukuran perusahaan memiliki arah hubungan yang positif sejauh ,522 terhadap audit delay. Dengan kata lain, semakin besar ukuran perusahaan maka audit delay akan semakin pendek, sebaliknya semakin kecil ukuran perusahaan maka audit delay akan semakin panjang. Dengan asumsi variabel lain bernilai tetap, dapat diartikan bahwa setiap kenaikan ukuran perusahaan sebesar 1 akan menyebabkan penurunan pada audit delay sebesar ,522, demikian pula penurunan ukuran perusahaan sebesar 1 akan menyebabkan kenaikan pada audit delay sebesar ,522.

Koefisien regresi variabel $\mathrm{X}_{2} \quad\left(\beta_{2}\right)$ bernilai 0,606. Hal ini menunjukkan bahwa ROA memiliki arah hubungan yang positif sejauh 0,606 terhadap audit delay. Dengan kata lain, semakin besar ROA maka audit delay akan semakin panjang, sebaliknya semakin kecil ROA maka audit delay akan semakin pendek. Dengan asumsi variabel lain bernilai tetap, dapat diartikan bahwa setiap kenaikan ROA sebesar 1 akan menyebabkan kenaikan pada audit delay sebesar 0,606, demikian pula penurunan ROA sebesar 1 akan menyebabkan penurunan pada audit delay sebesar 0,606.

Koefisien regresi variabel $X_{3} \quad\left(\beta_{3}\right)$ bernilai 39,493. Hal ini menunjukkan bahwa DAR memiliki arah hubungan yang positif sejauh 39,493 terhadap audit delay. Dengan kata lain, semakin besar DAR maka audit delay akan semakin panjang, sebaliknya semakin kecil DAR maka audit delay akan semakin pendek. Dengan asumsi variabel lain bernilai tetap, dapat diartikan bahwa setiap kenaikan DAR sebesar 1 akan menyebabkan kenaikan pada audit delay sebesar 39,493, demikian pula penurunan DAR sebesar 1 akan menyebabkan penurunan pada audit delay sebesar 39,493.

Nilai standard error $(\varepsilon)$ didapatkan sebesar 6,383 .

\section{Analisis Deskriptif}

Tabel 1. Output Descriptive Statistics

\begin{tabular}{lrrrrr} 
& & & & & \multicolumn{1}{c}{$\begin{array}{c}\text { Std. } \\
\text { Deviation }\end{array}$} \\
\hline $\mathrm{Y}$ & 99 & 46,00 & 172,00 & 79,0505 & 17,67586 \\
$\mathrm{X} 1$ & 99 &, 00 & 6,00 & 3,6970 & 2,88010 \\
$\mathrm{X} 2$ & 99 &, 00 & 28,64 & 7,8800 & 6,39993 \\
$\mathrm{X} 3$ & 99 &, 10 & 1,00 &, 3973 &, 17459 \\
\hline
\end{tabular}

Sumber : Hasil Olahan SPSS 19

Berdasarkan tabel diatas dapat dilihat bahwa jumlah sampel yang didapat, minimum, maximum, rata-rata dan standar deviasi masingmasing variabel.

\section{Uji Asumsi Dasar dan Klasik \\ Uji Normalitas}

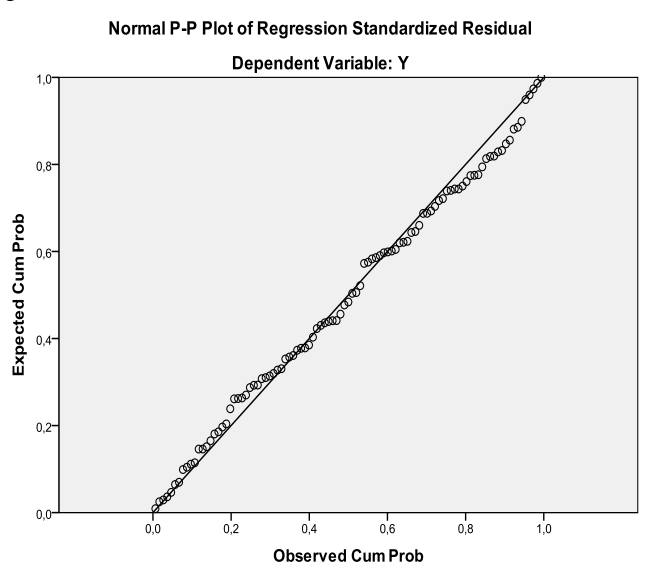

Sumber : Hasil Olahan SPSS 19

Gambar 2. P-P Plot Uji Normalitas

Berdasarkan gambar di atas dapat kita lihat bahwa titik-titik masih menyebar tidak jauh dari garis diagonal, maka dapat dijelaskan data 
dalam penelitian ini berdistribusi secara normal sehingga baik dan layak untuk digunakan dalam penelitian ini.

Tabel 2.

One-Sample Kolmogorov-Smirnov Test

\begin{tabular}{llrrr} 
& & \multicolumn{1}{c}{$\mathrm{Y}$} & \multicolumn{1}{c}{ X1 } & \multicolumn{1}{c}{ X2 } \\
\hline $\mathrm{N}$ & & 99 & 99 & 99 \\
Normal & Mean & 79,0505 & 3,6970 & 7,8800 \\
$\begin{array}{l}\text { Parameter } \\
\text { s,b }\end{array}$ & Std. & 17,67586 & 2,88010 & 6,39993 \\
& Deviation & & & \\
Most & Absolute &, 121 &, 354 &, 118 \\
Extreme & Positive &, 121 &, 274 &, 118 \\
Difference & Negative &,- 058 &,- 354 &,- 109 \\
s & & & & \\
Kolmogorov-Smirnov & 1,202 & 3,519 & 1,172 \\
Z & & & \\
Asymp. Sig. (2-tailed) &, 111 &, 000 &, 128 \\
\hline
\end{tabular}

Sumber : Hasil Olahan SPSS 19

Pada tabel diatas dapat dilihat bahwa unstandardized residual memiliki nilai signifikan (probabilitas) lebih dari 0,05, yang berarti bahwa data tersebut secara keseluruhan telah berdistribusi normal.

\section{Uji Multikolinieritas}

Tabel 3. Output Uji Multikolinearitas Coefficients $^{\mathrm{a}}$

\begin{tabular}{llll}
\multicolumn{3}{c}{ Coefficients $^{\mathrm{a}}$} \\
\cline { 2 - 4 } & \multirow{2}{*}{ Model } & \multicolumn{2}{c}{ Collinearity Statistics } \\
\cline { 3 - 4 } & Tolerance & VIF \\
\hline 1 & (Constant) & & \\
& X1 & .974 & 1.027 \\
X2 & .794 & 1.259 \\
X3 & .807 & 1.239 \\
& &
\end{tabular}

Sumber : Hasil Olahan SPSS 19

Pada tabel diatas dapat dilihat bahwa seluruh variabel bebas memiliki nilai Tolerance $>0.10$ dan VIF < 10, maka dapat dijelaskan bahwa model regresi ini tidak memiliki masalah multikolinieritas dan dapat digunakan dalam penelitian.

\section{Uji Autokorelasi}

Tabel 4. Output Uji Autokorelasi

\begin{tabular}{|c|c|c|c|c|c|}
\hline \multicolumn{6}{|c|}{ Model Summary $^{b}$} \\
\hline Model & $\mathrm{R}$ & $\begin{array}{c}\mathrm{R} \\
\text { Square }\end{array}$ & $\begin{array}{c}\text { Adjusted } \\
\text { R } \\
\text { Square }\end{array}$ & $\begin{array}{l}\text { Std. Error } \\
\text { of the } \\
\text { Estimate }\end{array}$ & $\begin{array}{l}\text { Durbin- } \\
\text { Watson }\end{array}$ \\
\hline 1 & $.365^{\mathrm{a}}$ & 0.133 & 0.106 & 16.71620 & 2.088 \\
\hline
\end{tabular}

Sumber : Hasil Olahan SPSS 19

Berdasarkan tabel diatas dapat dilihat bahwa nilai D-W sebesar 2,088 berada di antara batas atas atau upper bound (du) dan (3-du) yaitu diantara 1,5897 dan 2,4103 (4-1,5897). Oleh karena itu, maka dapat disimpulkan bahwa tidak ada autokorelasi dalam model regresi. Artinya variabel pengganggu pada periode yang diteliti dengan periode sebelumnya tidak terdapat kemiripan (korelasi) yang dapat membuat hasil penelitian menjadi bias. Dengan demikian, maka data dalam penelitian ini telah memenuhi asumsi klasik yang ketiga, yang menyatakan bahwa data harus bebas autokorelasi sebagai syarat yang mendasari model statistic parametric regresi berganda yang digunakan, sehingga kemudian pengambilan kesimpulan atas anaisis data dalam penelitian ini akan valid dan reliabel.

\section{Uji Heteroskedastisitas}

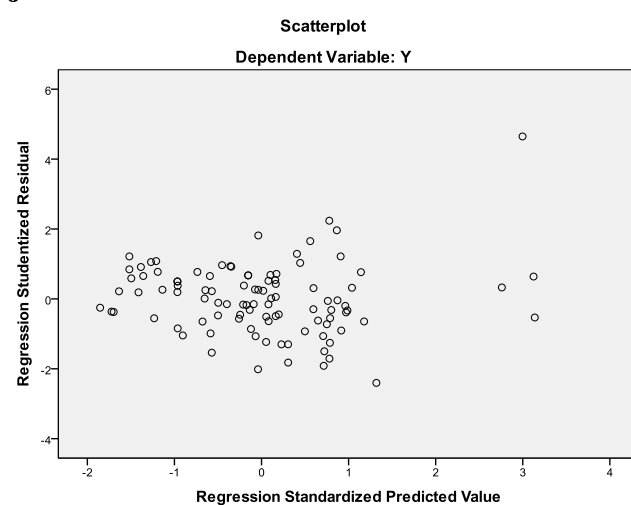

Sumber : Hasil Olahan SPSS 19

Gambar 3. Uji Heteroskedastisitas

Pada gambar diatas dapat dilihat bahwa titik-titik yang mewakili jumlah data penilaian tidak membentuk pola yang jelas, serta titik-titik menyebar diatas dan di bawah angka 0 pada sumbu Y. Oleh karena itu, maka dapat disimpulkan bahwa tidak terjadi heteroskedastisitas dalam model regresi. Artinya variance dari residual satu pengamatan ke pengamatan yang lain dalam penelitian ini tidak mengalami perbedaan yang dapat membuat hasil penelitian menjadi bias. Dengan demikian maka penelitian ini telah memenuhi asumsi klasik yang keempat, yang menyatakan bahwa data harus bebas heteroskedastisitas sebagai syarat yang mendasari model statistic parametrik regresi berganda yang digunakan, sehingga kemudian pengambilan keputusan atas analisis data dalam penelitian ini akan valid dan reliabel. 


\section{Uji Hipotesis Analisis Parsial (Uji t)}

Tabel 5. Hasil Pengujian Hipotesis

\begin{tabular}{ccccc}
\hline \multirow{2}{*}{ Variabel } & \multicolumn{2}{c}{$\begin{array}{c}\text { Berdasarkan } \\
\text { Uji t }\end{array}$} & \multicolumn{2}{c}{$\begin{array}{c}\text { Berdasarkan } \\
\text { Signifikansi }\end{array}$} \\
\cline { 2 - 5 } & $\mathrm{t}_{\text {hitung }}$ & $\mathrm{t}_{\text {tabel }}$ & Sig. & $\alpha$ \\
\hline $\mathrm{X} 1$ & .875 & 1.985 & 0.381 & 0.05 \\
\hline $\mathrm{X} 2$ & 2.047 & 1.985 & 0.043 & 0.05 \\
\hline $\mathrm{X} 3$ & 3.669 & 1.985 & 0.000 & 0.05 \\
\hline \multicolumn{3}{c}{ Sumber : Hasil Olahan SPSS 19 }
\end{tabular}

Berdasarkan tabel di atas, uji parsial dari hasil penelitian ini adalah:

Hipotesis pertama $\left(\mathrm{H}_{1}\right)$ menunjukkan bahwa $\mathrm{t}_{\text {hitung }}(, 875)>\mathrm{t}_{\text {tabel }}(1,985)$ dan signifikansi $(0,381)<\alpha(0,050)$, oleh karena itu maka hipotesis pertama $\left(\mathrm{H}_{1}\right)$ ditolak. Sehingga dapat disimpulkan bahwa ukuran perusahaan tidak berpengaruh terhadap audit delay.

Hipotesis kedua $\left(\mathrm{H}_{2}\right)$ menunjukkan bahwa $\mathrm{t}_{\text {hitung }}$ $(2,047)>\mathrm{t}_{\text {tabel }}(1,985)$ dan signifikansi $(0,043)<$ $\alpha(0,050)$, oleh karena itu maka hipotesis kedua $\left(\mathrm{H}_{2}\right)$ diterima. Sehingga dapat disimpulkan bahwa ROA berpengaruh positif terhadap audit delay.

Hipotesis ketiga $\left(\mathrm{H}_{3}\right)$ menunjukkan bahwa $\mathrm{t}_{\text {hitung }}$ $(3,669)>t_{\text {tabel }}(1,985)$ dan signifikansi $(0,000)<$ $\alpha(0,050)$, oleh karena itu maka hipotesis ketiga $\left(\mathrm{H}_{3}\right)$ diterima. Sehingga dapat disimpulkan bahwa DAR berpengaruh positif terhadap audit delay.

\section{Uji Hipotesis Analisis Stimulan (Uji F)}

Tabel 6. Hasil Pengujian Hipotesis Simultan

\begin{tabular}{lllc}
\hline & & \multicolumn{2}{c}{$\begin{array}{c}\text { Berdasarkan } \\
\text { Signifikansi }\end{array}$} \\
\hline Berdasarkan Uji F & Sig. & $\alpha$ \\
\hline $\mathrm{F}_{\text {hitung }}$ & $\mathrm{F}_{\text {tabel }}$ & 0.000 & 0.050 \\
\hline 8,876 & 2.70 & Sumber : Hasil Olahan SPSS 19
\end{tabular}

Berdasarkan tabel di atas, hasil pengujian hipotesis simultan $\left(\mathrm{H}_{4}\right)$ menunjukkan bahwa $F_{\text {hitung }}(8,876)>F_{\text {tabel }}(2,70)$ dan signifikansi $(0,000)<\alpha(0,050)$, oleh karena itu maka hipotesis simultan $\left(\mathrm{H}_{4}\right)$ diterima. Sehingga dapat disimpulkan bahwa ukuran perusahaan tidak berpengaruh, sedangkan ROA, dan DAR berpengaruh signifikan terhadap audit delay.

\section{Koefisien Determinasi $\left(\mathbf{R}^{2}\right)$}

Tabel 7. Output Uji Koefisien Determinasi $\left(\mathbf{R}^{2}\right)$

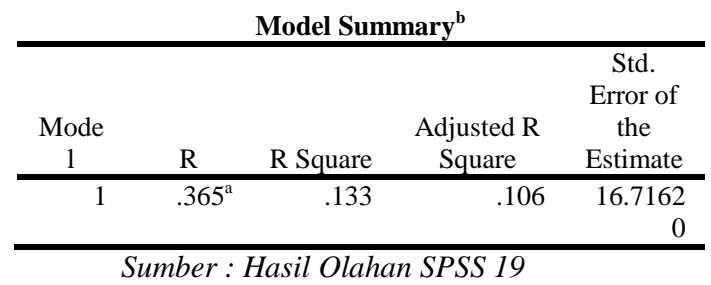

Berdasarkan tabel diatas dapat dilihat bahwa nilai adjusted $\mathrm{R}$ square adalah sebesar 0,106 . Hal ini menunjukkan bahwa $10,60 \%$ perubahan pada audit delay diterangkan oleh variabel-variabel independen (ukuran perusahaan, ROA, dan DAR) yang digunakan dalam model penelitian ini. Sedangkan sisanya $89,40 \%$ diterangkan oleh variabel lain yang tidak dimasukkan dalam penelitian.

\section{Pengaruh ukuran perusahaan terhadap audit delay}

Penolakan terhadap hipotesis pertama ini menunjukkan bahwa ukuran perusahaan memang secara signifikan tidak berpengaruh terhadap lamanya waktu penyelesaian laporan audit.

Hasil penelitian ini mengindikasikan bahwa semakin besar ukuran perusahaan yang diukur dari total aset atau kekayaan yang dimiliki oleh suatu perusahaan akan mempercepat waktu penyelesaian laporan audit. Hal ini disebabkan karena perusahaan besar umumnya sudah memiliki sistem yang canggih, sumber daya manusia yang lebih banyak dan kompeten dalam menyelesaikan laporan audit perusahaan serta pengendalian internal yang baik sehingga memudahkan perusahaan untuk memberikan data kepada auditor. Selain itu, perusahaan yang berskala besar cendrung memiliki dana yang lebih banyak untuk mengontrak auditor independen yang kompeten sehingga bisa memberikan insentif lebih besar. Menurut Penelitian Apriliane (2015) ukuran perusahaan berpengaruh signifikan terhadap audit delay. Sedangkan penolakan terhadap hipotesis pertama ini menunjukkan bahwa ukuran perusahaan memang secara signifikan tidak berpengaruh terhadap lamanya waktu penyelesaian laporan audit. Tidak berpengaruhnya ukuran perusahaan terhadap audit delay dalam penelitian ini sesuai dengan hasil yang dilakukan oleh Dewi Lestari (2010). 


\section{Pengaruh ROA terhadap audit delay}

Penerimaan terhadap hipotesis kedua ini menunjukkan bahwa tingkat profitabilitas yang dihitung dengan rasio ROA (Return On Assets) memang secara signifikan berpengaruh positif terhadap lamanya waktu penyelesaian laporan audit. Berpengaruhnya tingkat profitabilitas khususnya rasio ROA terhadap audit delay dalam penelitian ini sesuai dengan hasil yang dilakukan oleh Lianto dan Kusuma (2010).

Hasil penelitian ini mengindikasikan bahwa besarnya rasio ROA (Return On Assets) yang diukur dari kemampuan perusahaan dalam memanfaatkan asset untuk menghasilkan laba akan memperlambat waktu penyelesaian laporan audit. Hal ini disebabkan karena semakin besar kemampuan perusahaan untuk menghasilkan laba, maka transaksi penjualan yang ada dalam perusahaan tersebut akan semakin banyak. Dengan adanya laba yang besar, maka akan ada tuntutan dari pihak manajemen untuk mempercepat memberikan kabar baik kepada publik. Tapi disisi lain, auditor akan semakin berhati-hati dalam melihat setiap detail penjualan yang ada, apakah penjualan itu benar-benar terjadi atau hanya penjualan fiktif supaya perusahaan bisa menghasilkan laba. Karena kehati-hatian itulah yang membuat laporan audit akan lama selesai.

\section{Pengaruh DAR terhadap audit delay}

Penerimaan terhadap hipotesis ketiga ini menunjukkan bahwa tingkat solvabilitas yang dihitung dengan DAR (Debt to Asset Ratio) memang secara signifikan berpengaruh positif terhadap lamanya waktu penyelesaian laporan audit. Berpengaruhnya tingkat solvabilitas khususnya rasio DAR terhadap audit delay dalam penelitian ini sesuai dengan hasil yang dilakukan oleh Fika Ristin (2016), Muliadi Candra (2015), Hardika dan Vega (2013).

Hasil penelitian ini mengindikasikan bahwa semakin besar DAR (Debt to Asset Ratio) yang diukur dari kemampuan perusahaan dalam melunasi utang maka waktu penyelesaian laporan audit akan semakin panjang. Hal ini disebabkan karena perusahaan yang memiliki DAR tinggi menggambarkan kondisi perusahaan yang kurang baik atau gagal dan meningkatkan fokus auditor bahwa laporan keuangan kurang reliable. Hal ini karena tingginya DAR secara normal berhubungan dengan tingginya risiko. Ini merupakan hasil dari kesehatan finansial perusahaan yang buruk dimana mungkin terjadi karena manajemen yang buruk dan fraud. Fokus auditor dalam hal ini akan membutuhkan waktu yang lebih lama dalam melaksanakan proses audit karena harus mengumpulkan alat bukti yang lebih kompeten untuk meyakinkan kewajaran laporan keuangannya..

Pengaruh ukuran perusahaan, ROA, dan DAR terhadap audit delay

Penerimaan terhadap hipotesis simultan ini menunjukkan bahwa faktor internal (ukuran perusahaan, ROA, DAR) yang dipilih dalam penelitian secara bersamaan memang berpengaruh signifikan terhadap lamanya penyelesaian laporan audit.

Hasl penelitian ini mengindikasikan bahwa faktor ukuran perusahaan, ROA dan DAR dari dalam perusahaan merupakan perhatian penting perusahaan dalam menerima laporan audit dari laporan auditor independen.

\section{PENUTUP}

\section{Kesimpulan}

Berdasarkan hasil penelitian dan pembahasan yang telah dilakukan, maka kesimpulan yang dapat diambil adalah sebagai berikut : (1) Hasil pengujian hipotesis pertama menunjukkan bahwa ukuran perusahaan $\left(\mathrm{X}_{1}\right)$ secara parsial terbukti tidak berpengaruh signifikan terhadap audit delay sebagai dasar penyampaian laporan audit; (2) Hasil pengujian hipotesis kedua menunjukkan bahwa tingkat profitabilitas khususnya rasio ROA (Return On Assets) $\left(\mathrm{X}_{2}\right)$ secara parsial terbukti berpengaruh positif signifikan terhadap audit delay sebagai dasar penyampaian laporan audit; (3) Hasil pengujian hipotesis ketiga menunjukkan bahwa tingkat solvabilitas khususnya DAR (Debt to Assets Ratio $)\left(\mathrm{X}_{3}\right)$ secara parsial terbukti berpengaruh positif signifikan terhadap audit delay sebagai dasar penyampaian laporan audit; dan (4) Hasil pengujian hipotesis simultan menunjukkan bahwa ukuran perusahaan tidak berpengaruh, sedangkan ROA, dan DAR, secara simultan terbukti berpengaruh signifikan terhadap audit delay.

\section{Saran}

Berdasarkan kesimpulan serta pembahasan hasil penelitian yang ada, maka saran yang dapat peneliti berikan adalah sebagai berikut: (1) Dalam pembuatan laporan terutama laporan audit, perusahaan disarankan untuk memberikan perhatian pada faktor internal (ukuran perusahaan, tingkat profitabilitas/ROA, tingkat solvabilitas/DAR) yang menjadi variabel 
independen dalam penelitian ini. Karena variabel-variabel independen ini disimpulkan secara bersamaan (simultan) memiliki pengaruh yang signifikan terhadap signifikan terhadap audit delay sebagai dasar penyampaian laporan audit. (2) Bagi para auditor dan KAP penelitian ini bisa membantu mereka mengidentifikasi apa saja hal yang membuat pengerjaan laporan audit menjadi lama. Para auditor dapat mengoptimalkan kinerja dalam pembuatan laporan. Sedangkan KAP dapat bekerja sama dengan pihak-pihak yang lebih berkompeten supaya reputasi mereka tetap terjaga. (3) Para peneliti selanjutnya hendaklah menambahkan variabel-variabel independen yang diteliti terkait hubungannya dengan variabel dependen dalam penelitian ini. Karena hasil uji koefisien determinasi $\left(\mathrm{R}^{2}\right)$ menunjukkan bahwa variabel independen dalam penelitian ini hanya menjelaskan perubahan pada audit delay sebesar 10,60\% sedangkan sebesar $89,40 \%$ dijelaskan oleh variabel lain di luar variabel yang digunakan dalam penelitian ini. Beberapa variabel yang dapat ditambahkan adalah umur perusahaan karena dari umur perusahaan bisa dilihat berapa lama perusahaan itu bisa bertahan dalam persaingan pasar, Pos-pos luar biasa yang ada dalam laporan keuangan yang menjadi perhatian oleh auditor, Opini auditor dan Reputasi auditor. Para peneliti selanjutnya juga perlu memperluas sampel yang digunakan sehingga hasil penelitian dapat mewakili seluruh perusahaan go public yang ada di pasar modal Indonesia serta memperpanjang periode pengamatan, karena semakin lama interval waktu pengamatan, semakin besar pula kesempatan untuk memperoleh informasi tentang variabel mana yang sebaiknya digunakan untuk melakukan peramalan yang lebih akurat dalam penyampaian laporan audit.

\section{DAFTAR PUSTAKA}

Andi Kartika. (2011). Faktor - Faktor Yang Mempengaruhi Audit Delay Pada Perusahaan Manufaktur Yang Terdaftar Di Bursa Efek Indonesia Periode 2006 2009, Jurnal. Universitas Stikubank Semarang.

Ani Yulianti. (2011). Faktor-faktor Yang Berpengaruh Terhadap Audit Delay (Studi Empiris Pada Perusahaan yang Terdaftar di Bursa Efek Indonesia Tahun 2007-2008). Skripsi. Universitas Negeri Yogyakarta.
Arens, Alvin A, Randal J. Elder, Mark S. Beasley. (2010). Auditing and Assurance Services : An Integrated Approach 13th Edition, Pearson, Prentice Hall Inc.

Apriliane. (2015). Faktor-Faktor yang Mempengaruhi Audit Delay pada Perusahaan Pertambangan di Bursa Efek Indonesia Tahun 2008 - 2013 Skripsi. Universitas Negeri Yogyakarta.

BAPEPAM LK. (2003). Keputusan Ketua Badan Pengawas Pasar Modal dan Lembaga Keuangan Nomor: Kep36/PMK/2003.

BAPEPAM, 1996. Peraturan No. X.K.II. Kep. No. 80/PM/1996, 17 Januari 1996.

Candra, Muliadi. (2015). Faktor-Faktor yang Mempengaruhi Audit Delay pada Perusahaan Manufaktur di Bursa Efek Indonesia. Skripsi. Universitas Islam Negeri Sultan Syarif Kasim Riau.

Chambers, Anne E, and Stephen H. Pennman, (1984). The Timeliness of Reporting and The Stock Price Reaction to Earnings Announcements. Journal of Accounting Research. 22(1).

Dwi Marta Sanjaya, I Made. Ni Gusti Putu Wirawati. April (2016)..Analisis Faktorfaktor yang Mempengaruhi Ketepatan Pelaporan Keuangan pada Perusahaan Manufaktur yang Terdaftar di BEI. Fakultas Ekonomi dan Bisnis Universitas Udayana (Unud), Bali, Indonesia.

Endrianto, Wendy. (2010). Analisis Pengaruh Penerapan Basel dan Good Corporate Governance Terhadap Manajemen Risiko Pada PT. BANK NEGARA INDONESIA (PERSERO) Tbk. Tesis. Universitas Indonesia.

Febrianty. (2011). Faktor-Faktor yang Berpengaruh Terhadap Audit Delay Perusahaan Sektor Perdagangan yang Terdaftar di Bursa Efek Indonesia Periode 2007-2009. Jurnal Ekonomi dan Informasi Akuntansi (Jenius), 3(1).

Board (FASB) dalam Statement of Financial Concept (SFAC) No.1

Hardika, N.S \& Y. C. Vega G. (2013). FaktorFaktor yang Mempengaruhi Audit Delay pada Perusahaan Publik di Bursa Efek Indonesia. Jurnal Bisnis dan Kewirausahaan.9(3):274-285.

Hery. (2009). Akuntansi Keuangan Menengah 1. Jakarta: PT Bumi Aksara 
Ikatan Akuntan Indonesia. (2012). Standar Akuntansi Keuangan. Jakarta: Salemba Empat

Ikhsan dan Ishak. (2005)..Akuntansi Keperilakuan Edisi Indonesia. Salemba Empat, Jakarta.

Indah Putri. (2014). Faktor - Faktor Yang Berpengaruh Terhadap Audit Report Lag Pada Perusahaan Manufaktur Yang Terdaftar Di Bursa Efek Indonesia Periode Tahun 2008 - 2012. Fakultas Ekonomika dan Bisnis Universitas Diponegoro Semarang.

Indonesia, Undang-Undang Tentang Pasar Modal. Undang-Undang Nomor 8 Tahun 1995. LN No.64 Tahun 1995.

Iskandar, M.J. dan E. Trisnawati. (2010). Faktor-Faktor Yang Mempengaruhi Audit Report Lag Pada Perusahaan Yang Terdaftar Di Bursa Efek Indonesia, Jurnal Bisnis dan Akuntansi, 12 (3): 176

Juanita, Greta. (2012). Pengaruh Ukuran Kantor Akuntan Publik, Kepemilikan, Laba Rugi, Profitabilitas dan Solvabilitas Terhadap Audit Report Lag. Jurnal Bisnis dan Akuntansi 14(1).

Kartika, Andi. Maret. (2009). Faktor-faktor yang Mempengaruhi Audit Delay di Indonesia (Studi Empiris pada Perusahaan-perusahaan LQ 45 yang Terdaftar di Bursa Efek Jakarta). Fakultas Ekonomi Universitas Stikubank Semarang.

Kinanti, Irsalina. (2012). PengaruhFaktor Internal Dan EksternalTerhadap Audit Delay Pada Perusahaan Property Dan Real Estate Periode 2009-2011.

Kusumawardani, Fitria. (2012)..Faktor-Faktor yang Mempengaruhi Audit Delay pada Perusahaan Manufaktur. ISSN 22526765.

Lestari, Dewi. (2010). Analisis Faktor-Faktor yang Mempengeruhi Audit Delay: Studi Empiris Pada Perusahaan Consumer Goods yang Terdaftar di Bursa Efek Indonesia. Skripsi. Fakultas Ekonomi Universitas Diponegoro. Semarang.

Lianto,N \& Budi Hartono Kusuma, (2010). Faktor-Faktor Yang Berpengaruh Terhadap Audit Report Lag. Jurnal Bisnis dan Akuntansi, 12.

Mulyadi. Auditing (Pengauditan). (2002). Buku I Edisi Ke Enam, PT. Salemba Empat.
Noverta, Christian, Togasima dan Yulius Jogi Christiawan. (2014). Analisis FaktorFaktor yang Mempengaruhi Audit Report Lag pada Perusahaan yang Terdaftar di Bursa Efek Indonesia pada Tahun 2012. Business Accounting Review, 2 (2), 151-159.

Peraturan Otoritas Jasa Keuangan Nomor 29/POJK.04/2016 tentang Laporan Tahunan Emiten atau Perusahaan Publik

http://www.ojk.go.id/id/kanal/pasarmodal/regulasi/peraturanojk/Documents/Pages/POJK-LaporanTahunan-Emiten-PerusahaanPublik/POJK-LaporanTahunan.pdf\#search=penyampaian\%201a poran\%20tahunan, diakses 24 September 2017

Petronila, Thio Anastasia. (2007). Pengaruh Faktor Internal dan Eksternal Perusahaan terhadap Audit Report lag dan Timeless. Jurnal Akuntansi dan Keuangan. 10(1). 1-10.

Prabandari, Jeane Deart Meity dan Rustiana. (2007). Beberapa Faktor yang Berdampak pada Perbedaan Audit Delay (Studi Empiris Pada PerusahaanPerusahaan Keuangan yang Terdaftar di BEI). Jurnal Kinerja. 11(27).

Rachmawati, Sistya. (2008). Pengaruh Faktor Internal dan Eksternal Perusahaan Terhadap Audit Delay dan Timeliness. Jurnal Akuntansi dan Keuangan 10(1):1.

Ratnawaty and T. Sugiharto, (2005), Audit Delay pada Industri Real Estate dan Properti yang Terdaftar di Bursa Efek Jakarta dan Faktor yang Mempengaruhinya, Proceeding Seminar Nasional PESAT, 288-300

Risah. (2016). Analisis Faktor-faktor yang Mempengaruhi Audit Delay (Studi Empiris pada Perusahaan Manufaktur yang terdaftar di Bursa Efek Indonesia Tahun 2010 - 2015).

Ristin, Fika. (2016). Faktor-Faktor yang Mempengaruhi Audit Delay pada Perusahaan Manufaktur di Bursa Efek Indonesia. Universitas Hasanuddin.

Rochimawati. (2011). Analsis Diskriminan Audit Delay Pada Industri Keuangan Di Bursa Efek Indonesia (BEI). Skripsi. Universitas Gunadarma. Hlm 3. 
Salinan Surat Edaran Otoritas Jasa Keuangan Nomor 30/SEOJK.04/2016 tentang Bentuk dan Isi Laporan Tahunan Emiten atau Perusahaan Publik

http://www.ojk.go.id/id/kanal/pasarmodal/regulasi/surat-edaranojk/Documents/SAL\%20\%20SEOJK Laporan\%20Tahunan\%20E miten.pdf\#search=laporan\%20tahunan\% 20audit, diakses 21 September 2017

Sekaran, uma dan Roger Bougie. (2010). Edisi 5, Research Method For Business: A Skill Building Approach. John Wiley@ Sons, New York.

Setiawan, Heru. (2013). Pengaruh Ukuran Perusahaan, Reputasi Auditor, Opini Audit, Profitabilitas dan Solvabilitas terhadap Audit Delay pada Perusahaan Keuangan yang Terdaftar di Bursa Efek Indonesia periode 2009-2011. Skripsi. Fakultas Ekonomi dan Bisnis Universitas Islam Negeri Syarif Hidayatullah Jakarta.

Shinta, Widhiasari. Ni Made. I Ketut Budiartha. April. (2016). .Pengaruh Umur Perusahaan, Ukuran Perusahaan, Reputasi Auditor, dan Pergantian Auditor terhadap Audit Report Lag. Fakultas Ekonomi dan Bisnis Universitas Udayana (Unud), Bali, Indonesia.

Suartana, I. W. (2010). Akuntansi Keprilakuan. ANDI. Yogyakarta.

Syamsudin, Lukman. (2011). Manajemen Perusahaan; Konsep Aplikasi dalam perencanaan, pengawasan, dan pengambilan Keputusan. Jakarta: Rajawali Persada. terdaftar dibursa efek Indonesia pada sector industri barang konsumsi periode 2008-2011.Fakultas Bisnis dan Ekonomika.

Subekti, Imam. dan N.W. Widiyanti. (2004). Faktor-Faktor Yang Berpengaruh Terhadap Audit Delay di Indonesia. Simposium Nasional Akuntansi VII:9911002.

Suhendri. (2011). Analisis Faktor-faktor yang Mempengaruhi Audit Delay pada Perusahaan Perdagangan Besar Barang Produksi yang Terdaftar di Bursa Efek Indonesia pada Tahun 2008-2010. Pekanbaru: Sekolah Tinggi Ilmu Ekonomi Pelita Indonesia.
Undang-undang Nomor 21 Tahun 2011 tentang Otoritas Jasa Keuangan http://www.ojk.go.id/id/regulasi/otoritasjasa-keuangan/undangundang/Pages/undang-undang-nomor-21tahun-2011-tentang-otoritas-jasakeuangan.aspx, diakses 24 September 2017

Widosari, Shinta Altia dan Rahardja. (2012). Analisis Faktor-Faktor yang Berpengaruh Terhadap Audit Delay pada Perusahaan Manufaktur di Bursa Efek Indonesia Tahun 2008-2010. DIPONEGORO JOURNAL OF ACCOUNTING, 1(1):113.

Yadiati, Winwin. Teori Akuntansi: Suatu Pengantar, Jakarta: Kencana. 2007.

Yanuarizqi. (2013). Faktor Yang Mempengaruhi Audit Delay Pada Perusahaan Manufaktur Yang Terdaftar di Bursa Efek Indonesia Tahun 2011 2012.

http://staff.ui.ac.id/system/files/users/martani/m aterial/psak1penyajianlaporankeuangan.p

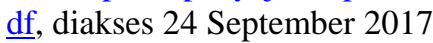

https://staff.blog.ui.ac.id/martani/files/2011/04/ ED_PSAK 1 2013-2013-JULI-23.pdf, diakses 24 September 2017

http://mbaconsultant.co.id/downloads/psak/PSA K-1-penyajian-laporan-keuangan-revisi2013.pdf, diakses 24 September 2017 www.idx.co.id 